\title{
Localization of Type I Benzodiazepine Receptors to Postsynaptic Densities in Bovine Brain ${ }^{1}$
}

\author{
ROSARIO R. TRIFILETTI AND SOLOMON H. SNYDER
}

Departments of Neuroscience, Pharmacology and Experimental Therapeutics, Psychiatry, and Behavioral Sciences, Johns Hopkins

University School of Medicine, Baltimore, Maryland 21205

\begin{abstract}
The subcellular localization of central-type benzodiazepine receptors in bovine cerebral cortex, cerebellum, hippocampus, and corpus striatum has been studied. In all regions except for the corpus striatum, benzodiazepine receptors are most highly enriched in purified postsynaptic densities (PSDs) prepared by Triton X-100/hypotonic lysis of purified synaptosomal plasma membranes. Benzodiazepine receptor enrichment in PSDs varies regionally, following the order cerebellum ( $\sim 8.5$-fold enriched relative to crude $P_{2}$ membranes) $>$ cerebral cortex $>$ hippocampus $>$ striatum (no significant enrichment); the percentage of putative type I benzodiazepine receptors in each of these brain regions follows the same rank order. In cerebral cortex, analysis of displacement of the benzodiazepine antagonist [ $\left.{ }^{3} \mathrm{H}\right] \mathrm{Ro}-15-$ 1788 by the type I-selective drug CL-218,872 reveals that PSDs contain type I benzodiazepine receptors exclusively; other subcellular fractions contain mixtures of type I and type II benzodiazepine receptors. Benzodiazepine receptors in PSDs resist further extraction with detergent but can be solubilized with detergent containing $\geq 0.2 \mathrm{M} \mathrm{NaCl}$. The enrichment of detergent-resistant/detergent-plus-salt extractable type I benzodiazepine receptors in PSDs might account in part for the differential solubilization of type I and type II benzodiazepine receptors from crude brain membranes previously reported.

The benzodiazepine-binding protein in cerebral cortical PSDs was identified by photoaffinity labeling with $\left[{ }^{3} \mathrm{H}\right]$ flunitrazepam followed by sodium dodecyl sulfate-polyacrylamide gel electrophoresis (SDS-PAGE) and fluorography. The PSD benzodiazepine-binding protein is identical in molecular weight to the binding protein from whole brain; partial tryptic and $\alpha$-chymotryptic fingerprints are also very similar in PSDs and whole brain.
\end{abstract}

A variety of evidence suggests the existence of multiple benzodiazepine receptors in mammalian brain (Squires et al., 1979; Lippa

Received June 4, 1984;

Accepted August 31, 1984

1 This work was supported by United States Public Health Service Grants DA-00266, MH-18501, and NS-16375, Research Scientist Award DA-00074 to S. H. S., National Institutes of Health Training Grant GM-07309 to R. R. T., and a grant of the McKnight Foundation. We thank Naomi Taylor for expert technical assistance and Dawn C. Dodson and Anita M. Hill for manuscript preparation.

${ }^{2}$ To whom correspondence and reprint requests should be addressed, at Department of Neuroscience, Johns Hopkins University School of Medicine, 725 North Wolfe Street, Baltimore, MD 21205. et al., 1982b). Certain non-benzodiazepine drugs such as the triazolopyridazine anxiolytic CL-218,872 and several alkyl $\beta$-carboline 3carboxylates appear to differentiate two benzodiazepine receptors in equilibrium radioligand binding studies (Nielsen and Braestrup, 1980; Lippa et al., 1982a, b). In the classification scheme proposed by Squires et al. (1979), benzodiazepine receptors are subdivided into two populations, termed "type I" and "type I" based on their affinity (high and low, respectively) for the triazolopyridazine $\mathrm{CL}$ 218,872 . Other studies suggest that alkyl $\beta$-carboline 3 -carboxylates also display a higher affinity for type I than for type II benzodiazepine receptors (Nielsen and Braestrup, 1980). Apparent type I and type II receptor populations can be physically separated by differential solubilization of crude brain membranes (Lo et al., 1982a, b). Extraction of crude (rat or bovine) brain membranes with $1 \%$ Triton X-100 (Lo et al., 1982a) or $2 \%$ sodium cholate (Lo et al., 1982b) yields a soluble receptor preparation enriched in type II receptors, whereas detergent-resistant type I receptors remain in the pellet. Further extraction of the pellet with detergent $/ 1 \mathrm{M} \mathrm{NaCl}$ can extract the type I receptor population. These results suggest that type I benzodiazepine receptors might be preferentially associated with some component of the neuronal cytoskeleton insoluble in nondenaturing detergents and that the type I and type II receptors might thus possess different intracellular localizations. Quantitative autoradiographic studies of benzodiazepine receptors in the rat substantia nigra following striatonigral denervation indicate that type II receptors are localized to the axons and terminals of the striatonigral pathway, whereas type I sites are postsynaptic (Lo et al., 1983). To oblain more direct information concerning the intracellular localization of the two apparent benzodiazepine receptor subpopulations, we now report a detailed analysis of the subcellular distribution of benzodiazepine receptors in bovine brain and show an enrichment of type I receptors in postsynaptic densities (PSDs).

\section{Materials and Methods}

Chemicals. [ $\left.{ }^{3} \mathrm{H}\right] \mathrm{Ro}-15-1788$ (specific activity, $87 \mathrm{Ci} / \mathrm{mmol}$ ), $\left[{ }^{3} \mathrm{H}\right]$ diazepam $(80 \mathrm{Ci} / \mathrm{mmol})$, and $\left[{ }^{3} \mathrm{H}\right]$ flunitrazepam $\left(\left[{ }^{3} \mathrm{H}\right] \mathrm{FNZ}\right)(87 \mathrm{Ci} / \mathrm{mmol})$ were obtained from New England Nuclear (Boston, MA). The detergents Triton $X-100$, sodium deoxycholate, sodium cholate, and sodium $N$-lauryl sarcosinate were obtained from Sigma Chemical Co. (St. Louis, MO). All other chemicals were reagent grade and obtained from standard chemical sources.

Subcellular fractionation. The subcellular fractionation procedure utilized was essentially that described by Cohen et al. (1977) for the preparation of PSDs from canine cerebral cortex, with minor modifications. This procedure was selected because the morphology, biochemical composition, and purity of the resulting PSDs have been extensively characterized (Blomberg et al., 1977).

Bovine brains were obtained from a local slaughterhouse. After stripping the meninges and dissecting appropriate regions, the tissue was homogenized in 4 vol of ice-cold solution $\mathrm{A}(0.32 \mathrm{M}$ sucrose containing $1 \mathrm{mM}$ $\mathrm{NaHCO}_{3}, 1 \mathrm{mM} \mathrm{MgCl}_{2}$, and $0.5 \mathrm{~mm} \mathrm{CaCl}$ ) by 12 strokes of a motor-driven Teflon-glass homogenizer $(0.25 \mathrm{~mm}$ clearance). Solution $\mathrm{A}$ was added to the homogenate to give a final tissue concentration of $10 \mathrm{~m} / \mathrm{gm}$ of original wet weight. The homogenate was centrifuged $10 \mathrm{~min}$ at $1,500 \times \mathrm{g}$ and the 

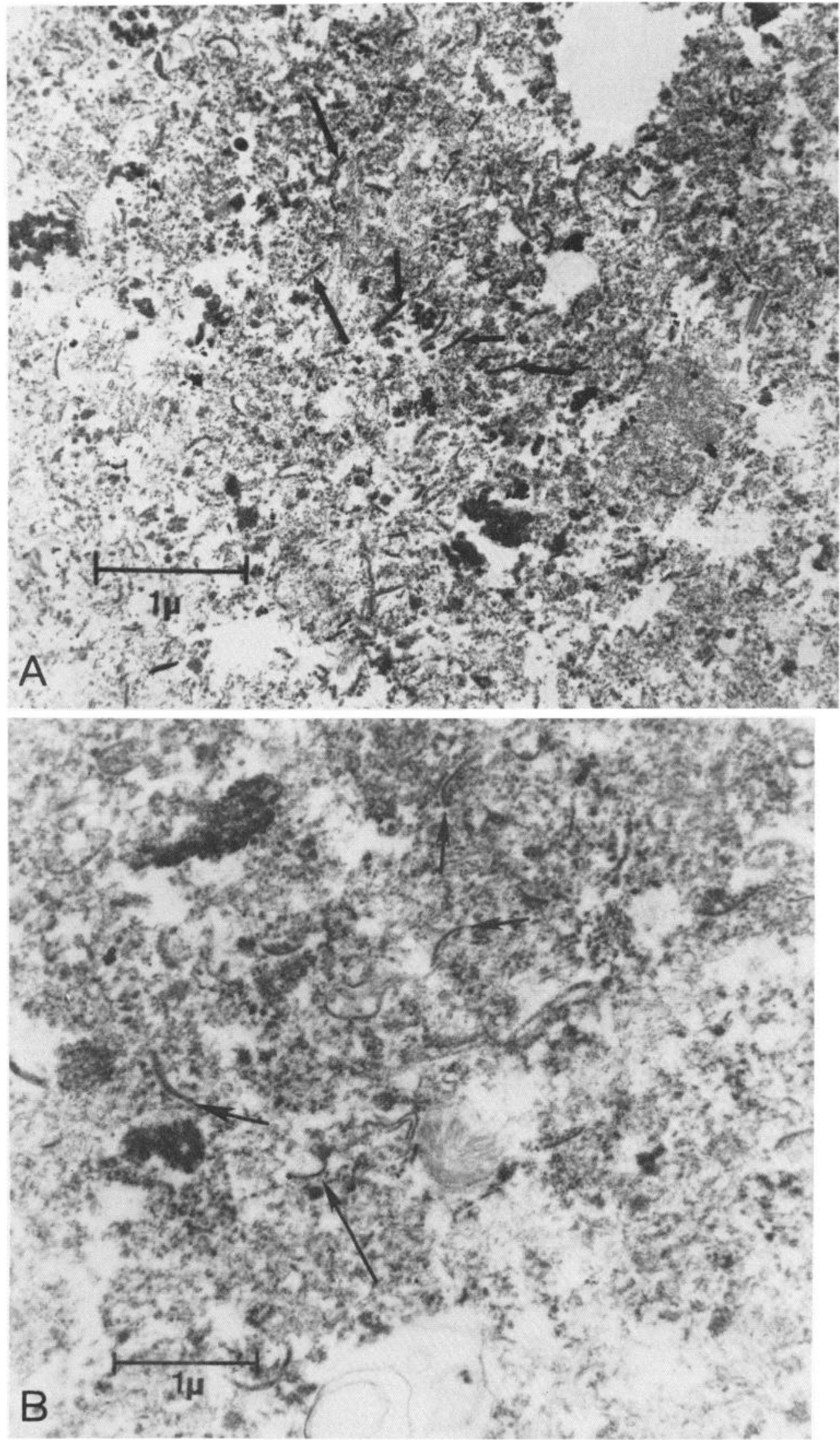

Figure 1. Electron micrographs of PSD from bovine hippocampus $(A)$ and bovine cerebellum $(B)$. Electron microscopy was performed as described under "Materials and Methods." Shown are thin sections through pellets from the PSD fraction, stained with $8 \%$ uranyl acetate $/ 4 \%$ lead citrate. Arrows indicate good examples of structures with morphology characteristics of PSDs. Magnification $\times 28,700$. 


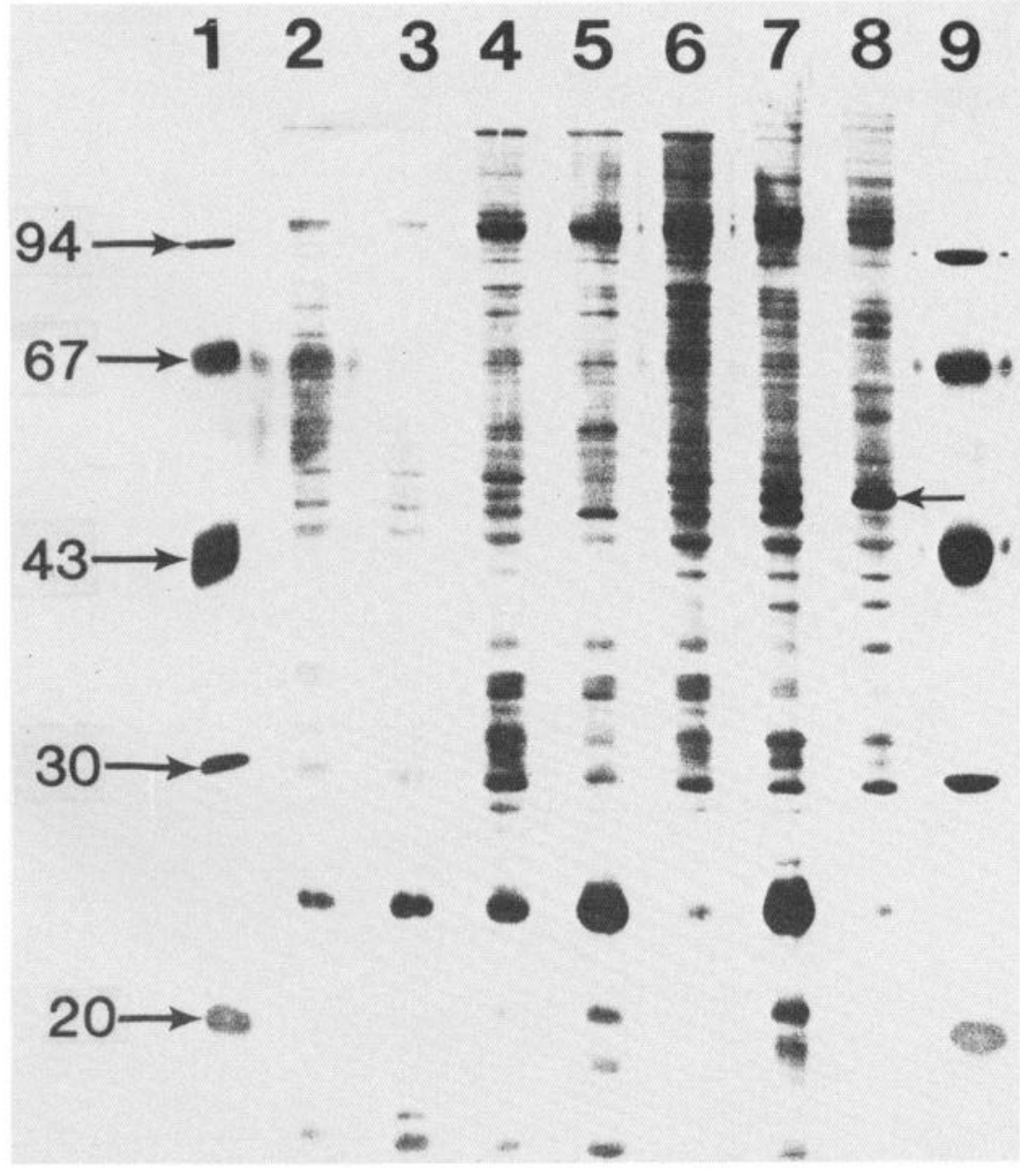

Figure 2. SDS-PAGE (10\%) patterns of various fractions from subcellular fractionation of bovine cerebral cortex. Subcellular fractionation was performed as described under " $\mathrm{Ma}$ terials and Methods." Each lane contained approximately 10 $\mu \mathrm{g}$ of protein as estimated by the method of Lowry et al. (1951). Protein was detected by the silver staining procedure of Wray et al. (1981). Lane contents were: (1) standard marker proteins (molecular weights, $\times 10^{3}$ ); (2) whole bovine cortex; (3) crude nuclear fraction; (4) crude $P_{2}$ fraction; (5) crude myelin fraction; (6) crude synaptosomal fraction; (7) crude mitochondrial fraction; (8) PSD fraction; (9) standard marker proteins.

TABLE ।

Regional variations in subcellular distribution of $\left.I^{3} \mathrm{H}\right] \mathrm{Ro}-15-1788$ binding

Subcellular fractionation was performed on tissue from various bovine brain regions as described under "Materials and Methods" using $12.5 \mathrm{nM}\left[{ }^{3} \mathrm{H}\right] \mathrm{Ro}$ 15-1788, a concentration sufficient to indicate the total number of binding sites. Values presented are the mean \pm SEM with number of independent experiments in parentheses. Values presented are the $B_{\max }$ of $\left[{ }^{3} \mathrm{H}\right] \mathrm{Ro}-15-1788$ (femtomoles per milligram of protein) in the given fraction, relative to the value determined in the crude $\mathrm{P}_{2}$ fraction; this allows direct comparison of enrichment in the various fractions. The absolute numerical values of $\left[{ }^{3} \mathrm{H}\right] \mathrm{Ro}-15-1788$ $B_{\max }$ for crude homogenates were (in a typical experiment) $455,200,231$, and $130 \mathrm{fmol} / \mathrm{mg}$ of protein in the cerebral cortex, cerebellum, hippocampus, and striatum, respectively.

\begin{tabular}{|c|c|c|c|c|}
\hline Subcellular Fraction & Cerebellum & Cerebral Cortex & Hippocampus & Corpus Striatum \\
\hline & \multicolumn{4}{|c|}{$\left[{ }^{3} \mathrm{H}\right] \mathrm{Ro}-15-1788$ Binding Sites (relative to crude $P_{2}$ ) } \\
\hline Crude homogenate & $1.0 \pm 0.2(3)$ & $0.98 \pm 0.18(4)$ & $0.92 \pm 0.03(3)$ & $0.92 \pm 0.02(3)$ \\
\hline Crude $\mathrm{P}_{2}$ & 1.0 & 1.0 & 1.0 & 1.0 \\
\hline \multirow[t]{2}{*}{ Crude snyaptosmal } & $2.2 \pm 0.2(5)$ & $2.2 \pm 0.6(6)$ & $1.5 \pm 0.1(3)$ & $0.96 \pm 0.04(3)$ \\
\hline & \multicolumn{4}{|c|}{ Relative Number of $\left[{ }^{3} \mathrm{H}\right] \mathrm{Ro}-15-1788$ Binding Sites (crude $\left.\mathrm{P}_{2}\right)$} \\
\hline Crude mitochondria & $1.0 \pm 0.2(5)$ & $1.4 \pm 0.4(5)$ & $1.4 \pm 0.1(3)$ & $1.1 \pm 0.3(3)$ \\
\hline
\end{tabular}

${ }^{a}$ Significantly different from cerebral cortex, $p<0.02$ (Student's two-tailed $t$ test).

${ }^{b}$ Significantly different from hippocampus or corpus striatum $(p<0.001)$.

supernatant was collected. Optionally, to increase the yield of the various subcellular fractions, the resulting pellet was resuspended to $10 \mathrm{ml} / \mathrm{gm}$ in solution A and centrifuged as before, and the supernatants from this and the previous centrifugation were combined. The supernatants were centrifuged 20 min at $48,000 \times g$ and the resulting pellet (termed "crude $P_{2}$ pellet") was resuspended in $2 \mathrm{vol}$ (based on original tissue $\mathrm{P}_{2}$ wet weight) of ice-cold solution $\mathrm{B}\left(0.32 \mathrm{M}\right.$ sucrose containing $\left.1 \mathrm{mM} \mathrm{NaHCO}_{3}\right)$ by 10 strokes of a Teflon-glass homogenizer. Fifteen milliliters of the homogenate were applied to a discontinuous gradient formed with $8 \mathrm{ml}$ of $0.85 \mathrm{M}$ sucrose in $1 \times 31 / 2$ inch polyallomer tubes. Gradients were centrifuged $2 \mathrm{hr}$ at $100,000 \times \mathrm{g}$ in an SW 27 rotor (Polyallomer tubes and rotor were from Beckman Instruments, Inc., Palo Alto, CA). Material floating on the $0.85 \mathrm{M}$ interface was termed the "crude myelin fraction," material settling at the $1.0 \mathrm{M}$ and $1.2 \mathrm{M}$ interface was termed the "crude synaptosomal fraction," and material pelleting was termed the "crude mitochondrial fraction." Very little material settled at the $0.85 \mathrm{M} /$ $1.0 \mathrm{M}$ interface and this was frequently not collected; when collected, it was termed the "crude Golgi/endoplasmic reticulum fraction." The various fractions were collected by diluting them in an equal volume of solution $\mathrm{B}$ and centrifuging $20 \mathrm{~min}$ at $48,000 \times \mathrm{g}$. To prepare purified PSDs, the pellet resulting from the crude synaptosomal fraction was resuspended by Teflonglass homogenization in ice-cold $6 \mathrm{~mm}$ Tris- $\mathrm{HCl}\left(\mathrm{pH} 8.0\right.$ at $\left.0^{\circ} \mathrm{C}\right)$ at a final concentration of $1 \mathrm{gm}$ of original wet weight/ml. An equal volume of ice-cold $1 \%$ Triton $X-100$ in distilled water was then added and the mixture was gently stirred $15 \mathrm{~min}$ at $4^{\circ} \mathrm{C}$. The mixture was centrifuged $20 \mathrm{~min}$ at 48,000 

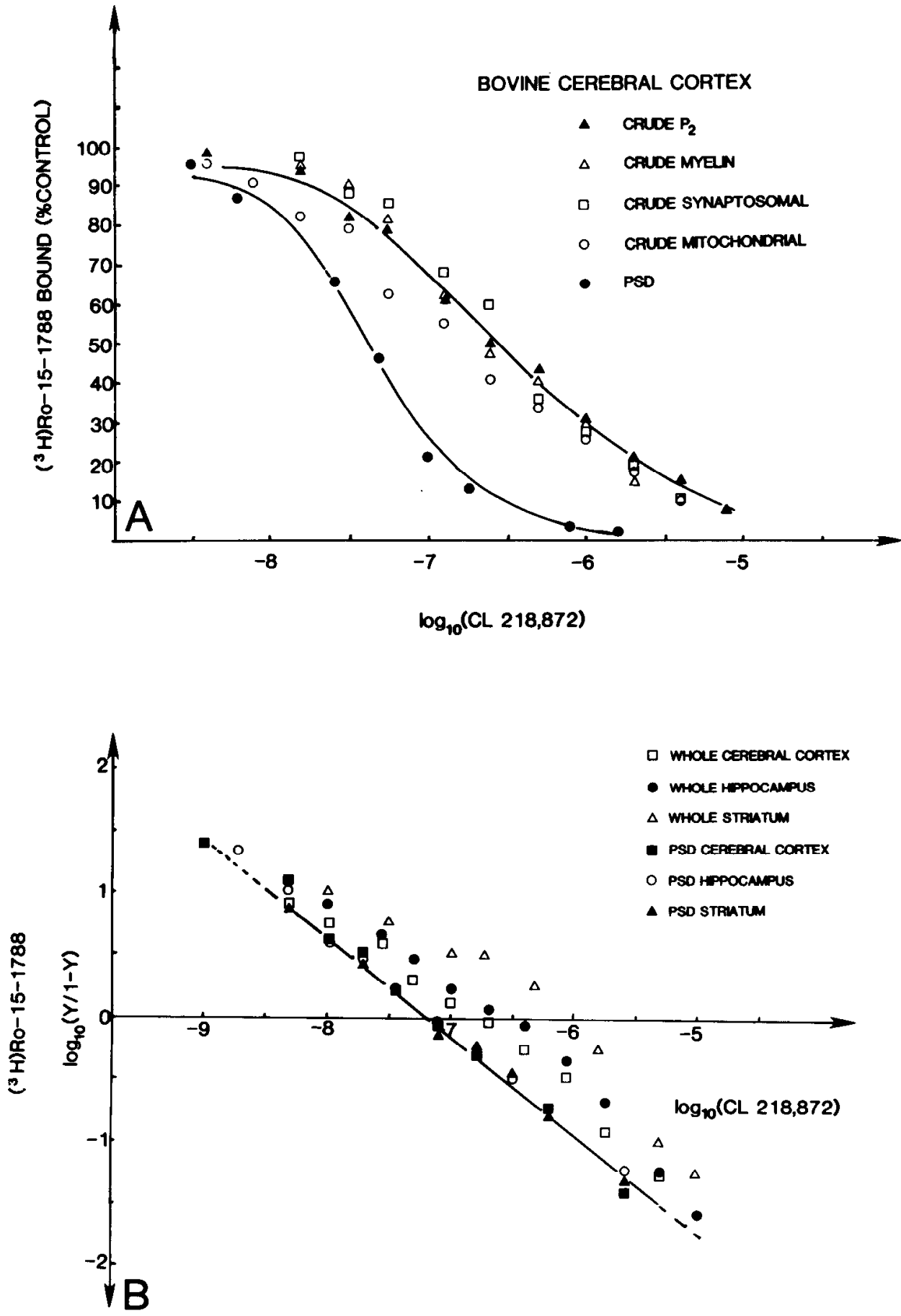

Figure 3. A, CL-218,872 inhibition of $\left[{ }^{3} \mathrm{H}\right]$ Ro-15-1788 binding in bovine cerebral cortex. Subcellular fractions were prepared and $\left[{ }^{3} \mathrm{H}\right] \mathrm{Ro}-15-1788$ binding was assayed as described under "Materials and Methods." Data are from a representative experiment replicated three times. The lines drawn are the unweighted least squares fit. For the PSD fractions, CL-218,872 displacement is monophasic with $\mathrm{IC}_{50}=85 \pm 5 \mathrm{nM}$, Hill coefficient, $0.98 \pm 0.03$. In $B$, the data of $A$ are presented as a Hill plot $\times g$, the resulting pellet was resuspended at $1 \mathrm{gm}$ of original wet weight $/ \mathrm{ml}$ in ice-cold solution $B$, and $15 \mathrm{ml}$ were applied to a second sucrose gradient formed with $8 \mathrm{ml}$ of $2.0 \mathrm{M}$ sucrose, $8 \mathrm{ml}$ of $1.5 \mathrm{M}$ sucrose, and $8 \mathrm{ml}$ of $1.0 \mathrm{M}$ sucrose. The gradients were centrifuged $2 \mathrm{hr}$ (or overnight) at $100,000 \times g$ in an SW 27 rotor. Most of the material applied to this gradient settled at the $1.5 \mathrm{~m} / 2.0 \mathrm{M}$ interface and was termed the "PSD fraction." This fraction was collected by diluting the gradient fraction into two parts of solution $B$ and centrifuging $30 \mathrm{~min}$ at $48,000 \times \mathrm{g}$. The entire procedure required 12 to 24 $\mathrm{hr}$, depending on the amount of material processed. Typical yields of this preparation were approximately $0.1 \mathrm{mg}$ of PSD protein/gm of original wet weight for each of the respective bovine brain regions. The amount of tissue (bovine cerebral cortex) routinely processed was about $200 \mathrm{gm}$ of wet weight.

Identities of all of the subcellular fractions collected were confirmed by electron microscopy. When used in radioligand binding studies or gel electrophoresis, fractions were resuspended by Polytron (Brinkmann Instruments, Inc., Westbury, NY) in $50 \mathrm{~mm}$ Tris-citrate $\left(\mathrm{pH} 7.2\right.$ at $\left.0^{\circ} \mathrm{C}\right)$ to a final protein concentration of $1 \mathrm{mg} / \mathrm{ml}$, determined by the method of Lowry et al. (1951). Fractions were stored as $1-\mathrm{ml}$ aliquots at $-80^{\circ} \mathrm{C}$ or were assayed directly.

Electron microscopy. Electron microscopy of uranyl acetate/lead citratestained thin-sectioned pellets of the various subcellular fractions was performed according to the procedures described by Cohen et al. (1977). All samples were examined in a Zeiss EM9S-2 electron microscope.

Radioligand binding assays. Assays for the binding activities of the benzodiazepine antagonist [ $\left.{ }^{3} \mathrm{H}\right] \mathrm{Ro}-15-1788$ and the benzodiazepine agonists $\left[{ }^{3} \mathrm{H}\right] \mathrm{FNZ}$ and $\left[{ }^{3} \mathrm{H}\right]$ diazepam were performed similarly. To $100 \mu \mathrm{l}$ of the appropriate subcellular fraction at $1 \mathrm{mg}$ of protein $/ \mathrm{ml}$ in $50 \mathrm{~mm}$ Tris-citrate $\left(\mathrm{pH} 7.2\right.$ at $0^{\circ} \mathrm{C}$ ) were added $50 \mu \mathrm{l}$ of the appropriate radioligand at the stated concentration and $50 \mu \mathrm{l}$ of Tris-citrate buffer (to define total binding). The mixture was incubated $90 \mathrm{~min}$ at $0^{\circ} \mathrm{C}$ and filtered over glass-fiber sheets (Schleicher and Schuell no. 32) on a Cell Harvester filtration manifold (model M 24-R, Brandel, Inc., Gaithersburg, MD) with thre日 3-ml washes of ice-cold $50 \mathrm{~mm}$ Tris-citrate buffer. Filters were counted by liquid scintillation spectrom- 
TABLE \|

Regulation of $\left[{ }^{3} \mathrm{H}\right]$ diazepam binding to subcellular fractions from bovine brain by GABA and chloride ion

Subcellular fractionation was performed as described under "Materials and Methods." To $100 \mu \mathrm{l}$ of tissue homogenate (1 mg of protein/ml) were added $50 \mu \mathrm{l}$ of $\left[{ }^{3} \mathrm{H}\right.$ ]diazepam (final assay concentration of $5 \mathrm{nM}$ ), $50 \mu \mathrm{l}$ of GABA (final assay concentration $10 \mu \mathrm{M}$ ) or $\mathrm{NaCl}$ (final assay concentration $200 \mathrm{mM}$ ) or $\mathrm{H}_{2} \mathrm{O}$, and $50 \mu \mathrm{l}$ of flunitrazepam (final concentration $10 \mu \mathrm{M}$ ) or buffer. Incubation and filtration were as described under "Materials and Methods." Values presented are the mean \pm SEM of triplicate determinations and represent the specific binding observed relative to that observed in the absence of modifier, expressed as a percentage.

\begin{tabular}{|c|c|c|c|c|}
\hline \multirow{3}{*}{ Fraction } & \multicolumn{4}{|c|}{$\left[{ }^{3} \mathrm{H}\right]$ Diazepam Binding (\% Control) } \\
\hline & \multicolumn{2}{|c|}{ Cerebellum } & \multicolumn{2}{|c|}{ Corpus Striatum } \\
\hline & $+10 \mu \mathrm{M}$ GABA & $+200 \mathrm{~mm} \mathrm{NaCl}$ & $+10 \mu \mathrm{M}$ GABA & $+200 \mathrm{mu} \mathrm{NaCl}$ \\
\hline Whole & $166 \pm 12$ & $137 \pm 8$ & $193 \pm 10$ & $163 \pm 15$ \\
\hline Crude $\mathrm{P}_{2}$ & $155 \pm 10$ & $135 \pm 9$ & $234 \pm 21$ & $138 \pm 8$ \\
\hline Synaptosome & $172 \pm 15$ & $122 \pm 6$ & $243 \pm 20$ & $108 \pm 14$ \\
\hline Mitochondria & $133 \pm 6$ & $107 \pm 9$ & $186 \pm 17$ & $109 \pm 15$ \\
\hline Postsynaptic densities & $185 \pm 11$ & $104 \pm 4^{a}$ & $198 \pm 44$ & $102 \pm 5^{a}$ \\
\hline
\end{tabular}

${ }^{a}$ Significantly different from whole brain membranes $(\rho<0.001)$ but not significantly different from 100 .

etry in $10 \mathrm{ml}$ of Formula 947 (New England Nuciear) at an efficiency of $46 \%$. For all binding assays, specific binding is reported and is defined as total binding less nonspecific binding

Photoaffinity labeling with $\Gamma^{3} \mathrm{H}$ flunitrazepam. To $1.0 \mathrm{ml}$ of the appropriate fraction [ $\left.{ }^{3} \mathrm{H}\right] \mathrm{FNZ}$ was added to a final concentration of $20 \mathrm{~nm}$. The mixture was incubated $60 \mathrm{~min}$ at $0^{\circ} \mathrm{C}$ and then exposed $30 \mathrm{~min}$ at $12 \mathrm{~cm}$ from a Black-Ray UV lamp (model B-100A; Ultraviolet Products, San Gabriel, CA; maximal power output at $366 \mathrm{~nm}, \sim 10 \times 10^{-3}$ watts $\mathrm{cm}^{-2}$ at $12 \mathrm{~cm}$ ). The sample was maintained at $0^{\circ} \mathrm{C}$ and was agitated constantly during illumination. "Nonspecific photoincorporation" of $\left[{ }^{3} \mathrm{H}\right] \mathrm{FNZ}$ was assessed in a similar fashion except that the initial incubation also contained unlabeled FNZ at a final concentration of $10 \mu \mathrm{M}$.

Gel electrophoresis. One-dimensional gel electrophoresis was performed in $10 \%$ polyacrylamide gel slabs according to the procedure of Laemmli (1970). Detection of proteins was performed by the silver-staining procedure of Wray et al. (1981). For detection of ${ }^{3} \mathrm{H}$-labeled proteins, the fluorographic enhancement procedure uof Laskey and Mills (1975) was utilized.

Partial proteolytic mapping. Partial proteolytic mapping of $\left.{ }^{3} \mathrm{H}\right] \mathrm{FNZ}$-photolabeled receptor with the enzymes trypsin or $\alpha$-chymotrypsin was performed by incubating $100 \mu \mathrm{l}$ of the appropriate fraction (photoaffinity labeled as described) with $25 \mu \mathrm{l}$ of $1 \mathrm{mg} / \mathrm{ml}$ of trypsin or $\alpha$-chymotrypsin (both enzymes from Miles Laboratories, Elkhardt, IN) for $30 \mathrm{~min}$ at $21^{\circ} \mathrm{C}$. Digestion was quenched by the addition of $25 \mu \mathrm{l}$ of an SDS-PAGE solubilizing buffer containing $10 \% \beta$-mercaptoethanol, $2 \%$ SDS, $5 \%$ glycerol in $1 \mathrm{M}$ Tris- $\mathrm{HCl}$ (pH 7.0), followed immediately by immersion in boiling water for $3 \mathrm{~min}$. Samples were cooled to room temperature and analyzed by gel electrophoresis with detection by fluorography, as described above.

Solubilization of receptor from PSDs. One milliliter of PSD fractions at 1.0 $\mathrm{mg}$ of protein $/ \mathrm{ml}$ centrifuged $20 \mathrm{~min}$ at $48,000 \times \mathrm{g}$. The pellets were resuspended by sonication in $1 \mathrm{ml}$ of the extraction buffer, which was 50 mm Tris-citrate containing various concentrations of $\mathrm{NaCl}$ and/or Triton $\mathrm{X}-100$, as noted. The sonicates were agitated $15 \mathrm{~min}$ at $4^{\circ} \mathrm{C}$ and then centrifuged $45 \mathrm{~min}$ at $100,000 \times g$ in a type $60 \mathrm{Ti}$ rotor. Supernatants were collected, and pellets were resuspended to the original volume in $50 \mathrm{~mm}$ Tris-citrate by sonication. Supernatants and resuspended pellets were assayed for $\left[{ }^{3} \mathrm{H}\right] \mathrm{Ro}-15-1788$ binding as previously described, except that filtration was now over glass-fiber filters which were presoaked $(5$ to $10 \mathrm{sec})$ in $0.3 \%$ polyethyleneimine (PEI) in $50 \mathrm{~mm}$ Tris-HCl. This PEl-soaked fiter assay for soluble benzodiazepine receptor binding is a slight modification of that described by Bruns et al. (1983) and gives comparable results to the polyethylene glycol/gamma globulin precipitation assay previously employed (Gavish et al., 1979). The percentage of receptor extracted and percentage recovery of specific binding (SPB) is calculated according to

$$
\% \text { extracted }=\left[(\mathrm{SPB})_{\text {sup }} /\left[(\mathrm{SPB})_{\text {sup }}+(\mathrm{SPB})_{\text {pel }}\right]\right] \times 100 \%
$$

$\%$ recovered $=\left[\left[(\mathrm{SPB})_{\text {sup }}+(\mathrm{SPB})_{\text {pee }}\right]_{e} /\left[(\mathrm{SPB})_{\text {sup }}\right.\right.$

$$
\left.\left.+(\mathrm{SPB})_{\mathrm{pel}}\right]_{0}\right] \times 100 \%
$$

where the subscripts $e$ and $o$ refer to the values in the appropriate extraction conditions and extraction in $50 \mathrm{~mm}$ Tris-citrate buffer, respectively.

In some experiments we monitored the subcellular distribution of covalently bound $\left[{ }^{3} \mathrm{H}\right] \mathrm{FNZ}$ following photoaffinity labeling. In these experiments, synaptosomes were photoaffinity labeled with [ $\left.{ }^{3} \mathrm{H}\right] \mathrm{FNZ}$ as described. Noncovalently bound $\left[{ }^{3} \mathrm{H}\right] \mathrm{FNZ}$ was removed by six wash cycles. Each wash cycle consisted of centrifuging membranes $10 \mathrm{~min}$ at $48,000 \times g$, resuspension (by Teflon-glass homogenizer) in the original volume of $0.32 \mathrm{M}$ sucrose containing $1 \mu \mathrm{M}$ unlabeled $\mathrm{FNZ}$, and a $20-\mathrm{min}$ incubation at $0^{\circ} \mathrm{C}$. Control experiments revealed that $>99 \%$ of the noncovalently bound $\left[{ }^{3} \mathrm{H}\right] \mathrm{FNZ}$ could be extracted in this way, the residual radioactivity representing $\left[{ }^{3} \mathrm{H}\right] \mathrm{FNZ}$ bound covalently to benzodiazepine receptors $(\geq 90 \%)$ and covalently bound to other proteins ("nonspecific photoincorporation") $(<10 \%)$. The extensively washed $\left[{ }^{3} \mathrm{H}\right] \mathrm{FNZ}$-photolabeled membranes were resuspended (by Teflonglass homogenizer) in $1 \mathrm{ml}$ of the appropriate extraction buffer, which was $50 \mathrm{~mm}$ Tris-citrate containing varying amounts of Triton X-100, sodium cholate, or sodium deoxycholate. Extraction was performed as previously described and the percentage of total receptor was extracted as estimated by equation 1 .

\section{Results}

Morphological and biochemical characteristics of PSDs from bovine brain. Representative electron micrographs of uranyl acetate/ lead citrate-stained thin sections through pellets of the PSD fraction are shown in Figure 1. With any of the four bovine brain regions studied, the procedure described here provides fractions greatly enriched in structures with morphology characteristic of PSDs. The PSDs appear as electron-dense structures about 30 to $50 \mathrm{~nm}$ wide, somewhat thicker than a typical cell membrane, and about 200 to $600 \mathrm{~nm}$ long. The PSDs seem somewhat longer when prepared from bovine cortex or cerebellum than when prepared from bovine hippocampus or striatum, but this observation has not been pursued by detailed morphometric analysis. In many instances, PSDs appear to possess a highly curved profile, thought to represent instances where the PSD is viewed in cross-section (Cohen et al., 1977); this is well seen in Figure $1 b$.

Analysis of PSD fractions from bovine cerebral cortex by SDS. PAGE with detection by silver staining reveals a fairly distinctive protein composition whose major protein constituent has an apparent $M_{r}$ of 51,000 , a protein selectively associated with PSDs (Matus and Taff-Jones, 1978) (Fig. 2). PSDs prepared from other bovine brain regions are also enriched in a 51,000-dalton peptide.

Thus, PSDs isolated from various bovine brain regions appear comparable in morphology and protein composition to what others have reported (Cotman and Taylor, 1972; Cohen et al., 1977; Matus and Taff-Jones, 1978).

Subcellular distribution of benzodiazepine receptors in bovine brain. Binding of the benzodiazepine antagonist [ $\left.{ }^{3} \mathrm{H}\right] \mathrm{Ro}-15-1788$ was assayed under conditions where receptors are fully saturated, so that the $B_{\max }$ is directly measured (Table I). Because the absolute number of benzodiazepine receptor sites varies from region to region in bovine brain, we have chosen to express the results in terms of the enrichment relative to the crude $\mathrm{P}_{2}$ pellet.

The subcellular distribution of benzodiazepine receptors varies considerably from brain region to brain region. In the cerebellum, cerebral cortex, and hippocampus, receptor binding is most enriched in PSD fractions. Significantly greater enrichment of benzo- 


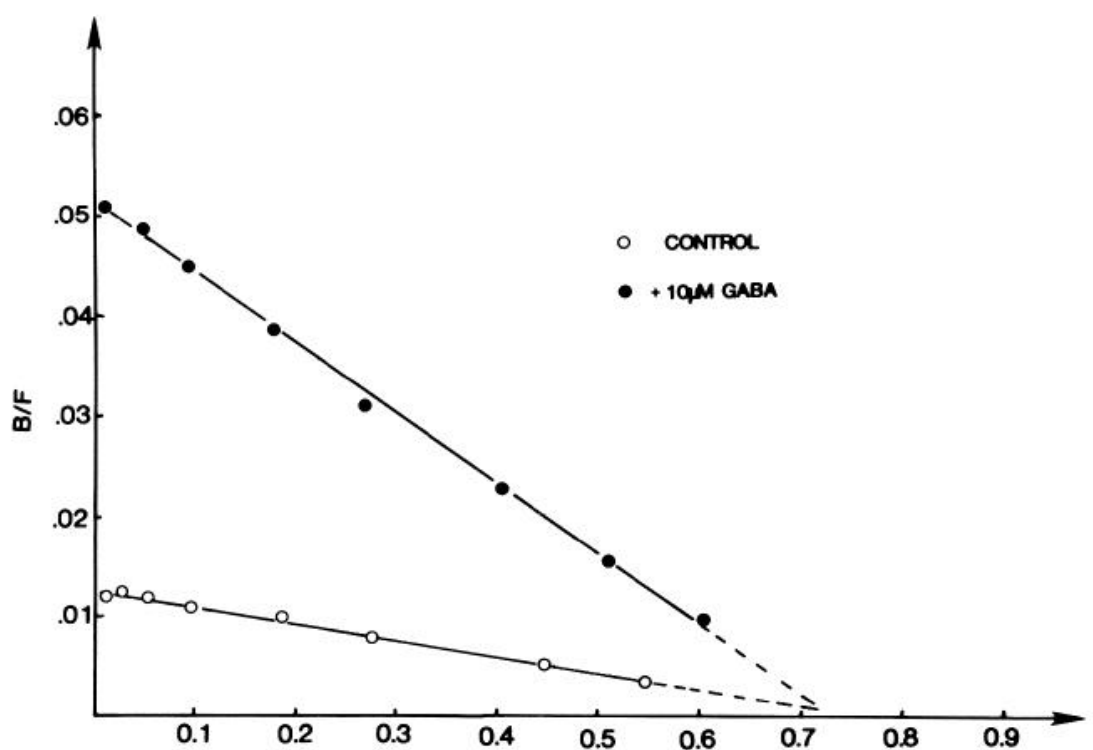

$\left({ }^{3}\right.$ H)DIAZEPAM SPECIFICALLY BOUND (pmol/mg protein)

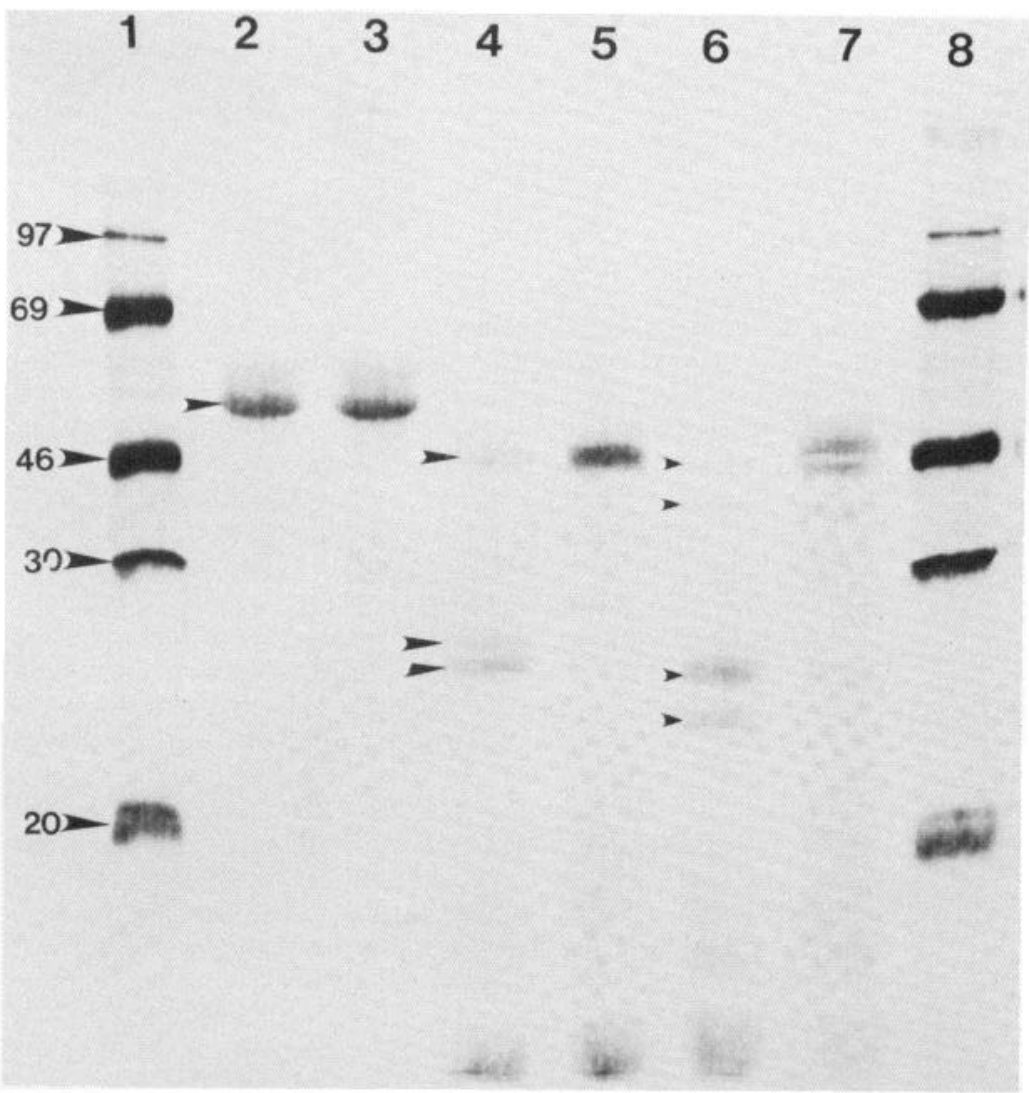

Figure 5. Partial tryptic and $\alpha$-chymotryptic maps of $\left[{ }^{3} \mathrm{H}\right] \mathrm{FNZ}$ photoaffinity-labeled benzodiazepine-binding protein from bovine cerebral cortical membranes and PSDs. Shown above is a fluorogram of radiolabeled proteins separated by $10 \%$ SDSPAGE. Subcellular fractions were prepared, photoaffinity labeled, and digested as described under "Materials and Methods." Lanes 2 to 7 each contained $100 \mu \mathrm{g}$ of protein. The PPO/ dimethylsulfoxide-enhanced gel was apposed to Kodak XOMAT-AR film for 30 days at $-80^{\circ} \mathrm{C}$ to generate the image shown above. Lane contents: $(1)\left[{ }^{14} \mathrm{C}\right]$ standard markers (from top to bottom: phosphorylase $\mathrm{B}$, bovine serum albumin, ovalbumin, carbonic anhydrase, and lactoglobulin A); (2) undigested PSD; (3) undigested whole brain membranes; (4) and (5) PSD and whole membranes, respectively, cleaved with trypsin; (6) and (7) PSD and whole membranes, respectively, cleaved with $\alpha$-chymotrypsin; $(8)\left[{ }^{14} \mathrm{C}\right]$ standard markers. Numbers to the left of lane 1 are molecular weights $\left(\times 10^{3}\right)$ of standards. diazepine receptors occurs in cerebellar than in cerebral cortical PSDs ( $p<0.02$, two-tailed Student's $t$ test), whereas cerebral cortical PSDs are more enriched in benzodiazepine receptors than in hippocampal or striatal PSDs $(p<0.001)$. Regional variations in benzodiazepine receptor enrichment in PSDs parallel regional variations in the proportion of type I receptors, namely, cerebellum > cerebral cortex $>$ hippocampus $>$ striatum (Asano et al., 1983; Trifiletti et al., 1984).

Subtype distribution of benzodiazepine receptors. To evaluate receptor subtypes, we examined the inhibition of $\left[{ }^{3} \mathrm{H}\right] \mathrm{Ro}-15-1788$ binding by CL-218,872 in whole brain and PSD in cerebral cortex, hippocampus, and striatum (Fig. 3a). In the cerebral cortex and hippocampus, Hill plots for CL-218,872 displacement of $\left[{ }^{3} \mathrm{H}\right] \mathrm{Ro}-15$ 1788 are curvilinear, consistent with the notion that CL-218,872 differentiates multiple receptors in these regions. By contrast, comparable plots for PSDs are monophasic with pseudo-Hill coefficients of 1.0. CL-218,872 appears more potent in blocking [ $\left.{ }^{3} \mathrm{H}\right] \mathrm{Ro}-15-1788$ binding to PSDs than whole membranes, an effect most dramatic in the striatum. One possible explanation for the apparent increased potency of CL-218,872 in PSDs would be a variation in the dissociation constant $\left(K_{D}\right)$ for $\left[{ }^{3} \mathrm{H}\right] \mathrm{Ro}-15-1788$. However, Scatchard plot analysis of $\left[{ }^{3} \mathrm{H}\right] \mathrm{Ro}-15-1788$ binding shows $K_{D}$ values in PSDs similar 


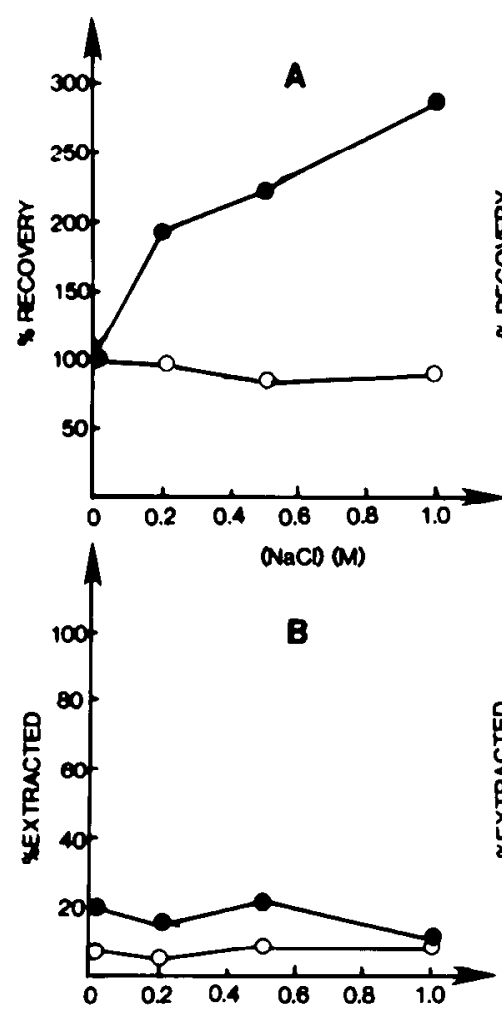

$\mathrm{NaCD}$ (M)
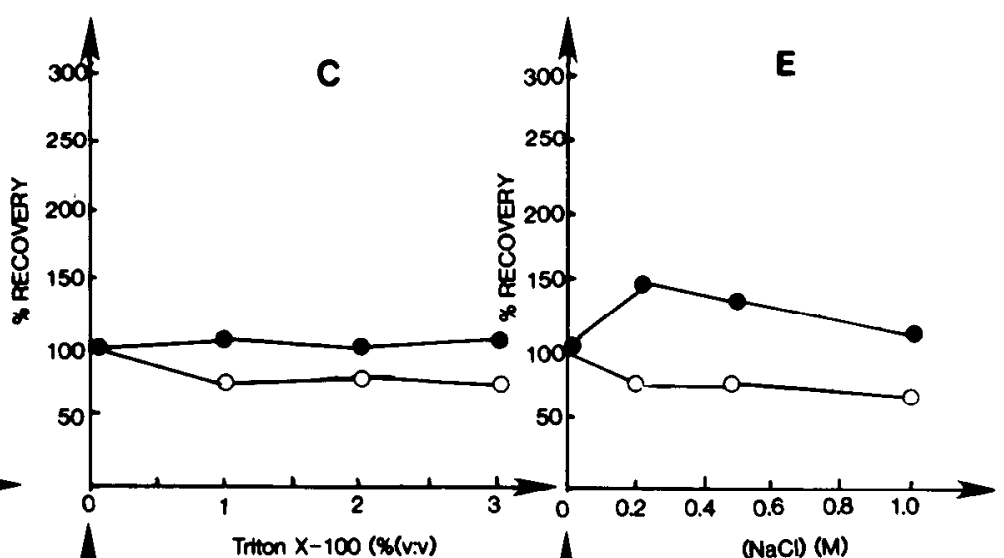

D

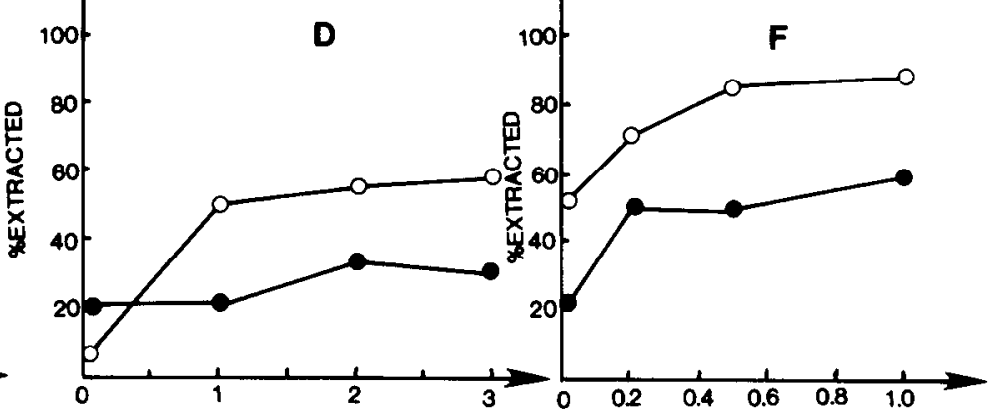

Titton X-100 (\%(v:v)

$\mathrm{ONaCD}(\mathrm{M})$

Figure 6. Extraction of $\left[{ }^{3} \mathrm{H}\right] \mathrm{Ro}-15-1788$ binding activity from crude $\mathrm{P}_{2}$ membranes $(O)$ and PSDs $(O)$ from bovine cerebral cortex. Subcellular fractionation was performed as described under "Materials and Methods." $\left.{ }^{3} \mathrm{H}\right] \mathrm{Ro}-15-1788$ binding was assayed at a final ligand concentration of $12.5 \mathrm{nM}$, as described under "Materials and Methods." Percentages of $\left[{ }^{3} \mathrm{H}\right] \mathrm{Ro}-15-1788$ binding activity extracted and recovered were calculated as described under "Materials and Methods." Data are from a representative experiment which was replicated with very similar results. $A$ and $B$, Percentage recovery and extraction of $\left[{ }^{3} \mathrm{H}\right] \mathrm{Ro}-$ $15-1788$ binding activity by various concentrations of $\mathrm{NaCl}$ in $50 \mathrm{~mm}$ Tris-citrate $(\mathrm{pH} \mathrm{7.2).} C$ and $D$. Similar to $A$ and $B$ but using various concentrations of Triton X-100 in buffer. $E$ and $F$, Percentage recovery and extraction of $\left[{ }^{3} \mathrm{H}\right] \mathrm{Ro}-15-1788$ binding activity after treatment with $1 \%$ Triton $X-100$ in buffer plus varying concentrations of $\mathrm{NaCl}$.

to those in whole membrane fractions (data not shown). Inhibition of $\left[{ }^{3} \mathrm{H}\right] \mathrm{Ro}-15-1788$ binding by $\mathrm{CL}-218,872$ displays a pseudo-Hill coefficient of 1.0 only in the PSD fraction of various brain regions (Fig. 3b).

Regulation of PSD benzodiazepine receptor binding by GABA and chloride ion. GABA stimulates $\left[{ }^{3} \mathrm{H}\right]$ diazepam binding to both whole membranes and PSDs from bovine cerebellum and corpus striatum in a dose-dependent manner via a decrease in $K_{0}$ with no change in $B_{\max }$ (Table II, Fig. 4). By contrast, chloride effects are different in crude membranes and PSDs. Chloride enhancement of $\left[{ }^{3} \mathrm{H}\right]$ diazepam binding, readily detected in crude membranes, is not apparent in PSDs from cerebellum or striatum.

Properties of the benzodiazepine-binding protein in bovine brain PSDs. We compared the native molecular weight of the $\left[{ }^{3} \mathrm{H}\right] \mathrm{FNZ}$ photoaffinity-labeled protein from whole membranes and PSDs (Fig. 5). A major band of apparent $M_{r}=50,000 \pm 1,000$ is labeled in each case. Other minor bands represent nonspecific photoincorporation unaffected by $10 \mu \mathrm{M}$ FNZ which abolishes labeling of the major band.

It is possible that the native photolabeled species in crude brain membranes and PSDs differ in structure but have similar molecular weights. Recently, we described procedures to obtain reproducible partial proteolytic maps of $\left[{ }^{3} \mathrm{H}\right] \mathrm{FNZ}$ photoaffinity-labeled benzodiazepine receptors (Trifiletti and Snyder, 1983). Digestion of both crude membranes and PSD [ $\left.{ }^{3} \mathrm{H}\right] \mathrm{FNZ}$-photolabeled receptors with trypsin and $\alpha$-chymotrypsin yield patterns which, apart from kinetic differences, are identical (Fig. 5). In both preparations trypsin cleaves the specifically photolabeled species into polypeptides of apparent $M_{\mathrm{r}}$ $=45,000,27,000$, and 25,000 , whereas $\alpha$-chymotrypsin cleaves the 51,000-dalton native binding subunit into fragments of apparent $M_{r}$ $=44,000,27,000$, and 24,000.

Solubilization of benzodiazepine receptors from PSDs. To assess possible interactions of benzodiazepine receptors with the PSD matrix, we have examined conditions under which benzodiazepine receptors may be detached from $P S D s$, utilizing various concentrations of $\mathrm{NaCl}$ and Triton $\mathrm{X}-100$, alone or in combination, to extract $\left[{ }^{3} \mathrm{H}\right]$ Ro-15-1788 binding activity from crude $\mathrm{P}_{2}$ membranes and PSDs from bovine cerebral cortex (Fig. 6). Extraction of crude $P_{2}$ membranes or PSDs with $50 \mathrm{~mm}$ Tris-citrate $(\mathrm{pH} \mathrm{7.2)}$ containing $\mathrm{NaCl}$ in concentrations up to $1 \mathrm{M}$ does not appreciably extract activity. This suggests that interaction of benzodiazepine receptors with the PSD matrix is not dominated by simple ionic forces, which would be attenuated in high ionic strength media. Interestingly, the salt extraction reproducibly enhances the amount of benzodiazepine receptor binding in PSDs but not in crude $\mathrm{P}_{2}$ membranes. Such results would be expected if a tonic inhibitor of benzodiazepine binding were released from the PSDs by $\mathrm{NaCl}$ treatment. PSD benzodiazepine receptors appear more resistant to extraction with the non-ionic detergent Triton $X-100$ than receptors from the crude $P_{2}$ pellet, there being little extraction at Triton X-100 concentrations up to $3 \%(\mathrm{w} / \mathrm{V})$. However, binding activity can be fully recovered in the PSD pellet. Treatment of PSDs with $1 \%$ Triton X-100 containing various concentrations of $\mathrm{NaCl}$ extracts [ ${ }^{3} \mathrm{H}$ Ro- $15-1788$ binding activity from both crude $\mathrm{P}_{2}$ membranes and PSDs.

Solubilization of benzodiazepine receptors from synaptosomal membranes by detergents other than Triton X-100. PSDs have been prepared using detergents other than Triton $X-100$. Detergents successfully used include sodium $\mathrm{N}$-lauryl sarcosinate (Cotman and 


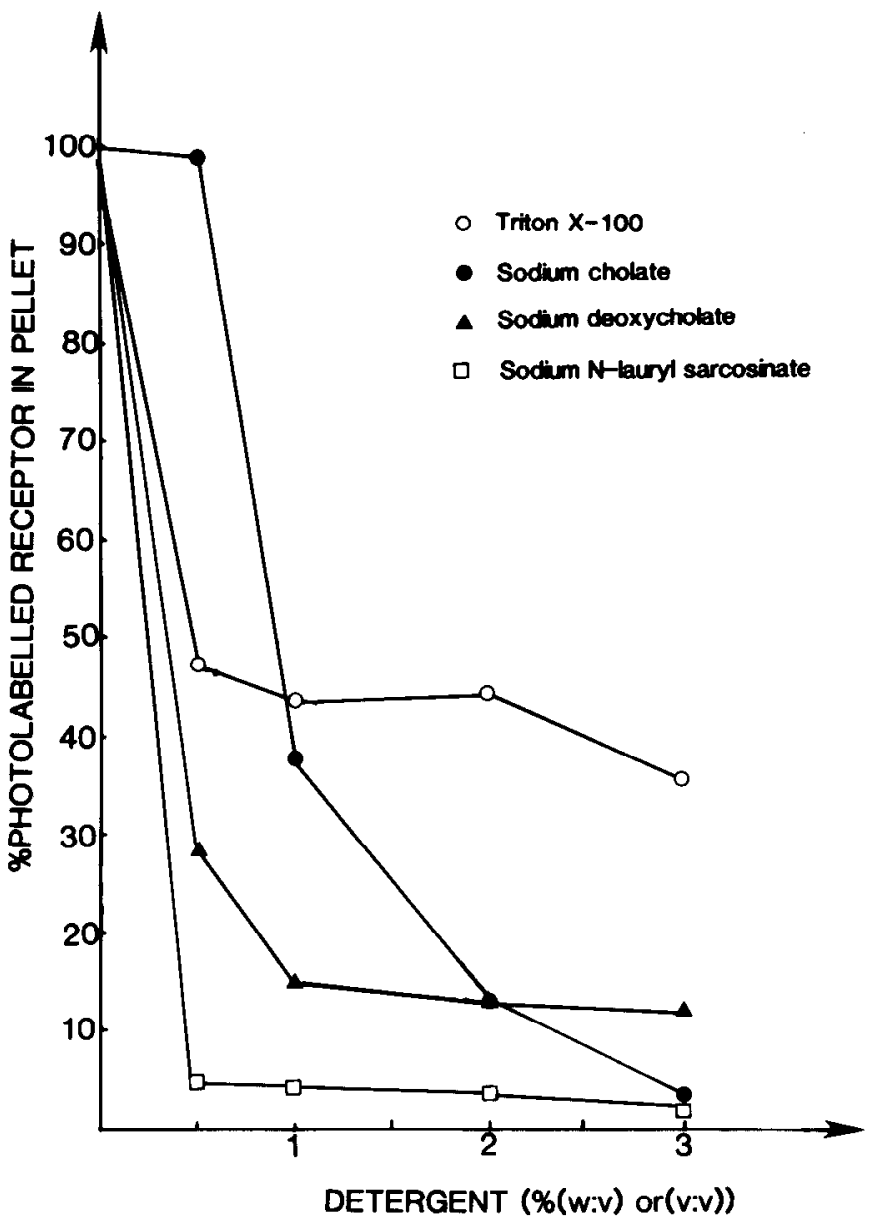

Figure 7. Extraction of $\left[{ }^{3} \mathrm{H}\right] \mathrm{FNZ}$ photoaffinity-labeled benzodiazepine receptors from bovine cerebral cortical synaptosomal membranes by various detergents. Crude synaptosomal membranes from bovine cerebral cortex were prepared and photoaffinity labeled with $\left[{ }^{3} \mathrm{H}\right] \mathrm{FNZ}$ as described under "Materials and Methods." Photolabeled synaptosomes were extracted with detergents at various concentrations, each made in $50 \mathrm{~mm}$ Tris-citrate (pH 7.2), as described under "Materials and Methods." The ordinate is $100 \%-$ (percentage of receptor extracted), calculated as described under "Materials and Methods." Data are from a representative experiment which was replicated with less than $10 \%$ variation.

Taylor, 1972) and sodium deoxycholate (Matus and Taff-Jones, 1978). Matus and Taff-Jones (1978) systematically evaluated the morphology and protein composition of junctional structures produced by these detergents. We examined the ability of several detergents to solubilize receptors from cerebral synaptic membranes labeled by photoaffinity treatment with $\left[{ }^{3} \mathrm{H}\right] \mathrm{FNZ}$. With Triton $\mathrm{X}-100$ only about $50 \%$ of the photolabeled receptors are extracted (Fig. 7). By contrast, sodium deoxycholate and sodium $N$-lauryl sarcosinate extract photolabeled receptors more completely. Matus and Taff-Jones (1978) have shown that the latter two detergents act upon synaptosomal membranes to produce a PSD "scaffold" structure they termed the postsynaptic junctional lattice (PJL). These results suggest that benzodiazepine receptors are not associated with the PJL. Sodium cholate, which extracts protein and phospholipid from synaptosomal plasma membranes, but otherwise causes little alteration in synaptosomal morphology, also effectively extracts photolabeled receptor.

\section{Discussion}

The major finding of the present study is that type I benzodiazepine receptors in bovine brain are considerably enriched in a subcellular fraction with the morphological and biochemical characteristics of PSDs. Evidence for this conclusion includes the following.
(1) In bovine cerebral cortex, cerebellum, and hippocampus, receptor density (number of sites per milligram of protein) is highest in PSDs. (2) The percentage of enrichment of benzodiazepine receptors in PSDs relative to crude $P_{2}$ pellet is significantly greater in those brain regions possessing a higher proportion of type I receptors. (3) Subcellular fractions other than PSDs contain a mixed population of type I/type II receptors, whereas PSDs have a relatively homogeneous population of type I receptors. (4) Benzodiazepine receptors in PSDs are regulated by GABA but not chloride ion. This resembles the behavior of soluble type I benzodiazepine receptors prepared by differential solubilization of crude membranes (Lo and Snyder, 1983). The relationship of at least some GABA receptors and benzodiazepine receptors accords with the localization of $\left[{ }^{3} \mathrm{H}\right]$ muscimol-labeled GABA receptors in PSDs (Matus et al., 1981). (5) The detergent solubility properties of benzodiazepine receptors in PSDs appear quite similar to those reported for type I receptors in crude brain membranes (Lo et al., 1982a, b); both PSD and type I benzodiazepine receptors resist detergent extraction but can be extracted by detergent containing high concentrations $(\geq 0.2 \mathrm{M})$ of salt.

A localization of type I receptors to PSDs fits with autoradiographic evidence of their postsynaptic occurrence, at least in the striatonigral pathway (Lo et al., 1983). The absence of type II receptors from PSDs and the readiness with which type II receptors are solubilized by detergent, on the other hand, agrees with autoradiographic evidence for a nerve terminal localization. The depletion of type ॥ receptors in the rat substantia nigra following lesions of the descending striatonigral pathway had indicated a localization of type ॥ receptors to terminals of this pathway (Lo et al., 1983). Whether type $\|$ receptors have this type of localization in other areas is unclear. Type II receptors might even be associated with PSDs but may be detached from them during the detergent treatment used in PSD preparation. In preliminary experiments, we were unable to prepare PSDs without the use of detergents as reported recently (Ratner and Mahler, 1983).

It is difficult to ascertain whether all type / receptors are associated with PSDs. The yield of PSDs in the subcellular fractionation employed is not readily quantified. The resistance to detergent extraction is a characteristic property of PSDs. The similar response to detergents of type I receptors and PSDs suggests that all type I receptors may be associated with PSDs.

The regulation of soluble type I (Lo and Snyder, 1983) and PSD benzodiazepine receptors appears similar; both are regulated by GABA but not by chloride ion. The lack of response to chloride ion might come from treatment with detergent. However, Type II benzodiazepine receptors solubilized by Triton X-100 preserve their regulation by chloride ion. Our finding that the $\left[{ }^{3} \mathrm{H}\right] \mathrm{FNZ}$-photolabeled receptors in PSDs and crude membranes possess similar native molecular weights, as well as partial tryptic and chymotryptic maps, strongly suggests that the benzodiazepine-binding protein in PSDs has an amino acid sequence similar to those in other intracellular structures. Of course, subtle structural differences such as single amino acid substitutions or post-translational modifications cannot be ruled out.

The response of [ $\left.{ }^{3} \mathrm{H}\right] \mathrm{FNZ}$-photolabeled synaptosomes to various detergents suggests that benzodiazepine receptors are not associated with the PJL as defined by Matus and Taff-Jones (1978). In a previous study (Matus et al., 1981), [ $\left.{ }^{3} \mathrm{H}\right]$ muscimol-binding sites were also enriched in PSDs but absent from the PJL. As we have monitored photoaffinity-labeled receptors in this study, we have avoided the possibility of loss of activity in the preparation of the PJL.

\section{References}

Asano, T., Y. Yamada, and N. Ogasawara (1983) Characterization of the solubilized GABA and benzodiazepine receptors from various regions of bovine brain. J. Neurochem. 40: 209-214.

Blomberg, F., R. S. Cohen, and P. Siekevitz (1977) The structure of postsyn- 
aptic densities isolated from dog cerebral cortex. II. Characterization and arrangement of some of the major proteins within the structure. J. Cell Biol. 74: 204-225.

Bruns, R. F., K. Lawson-Wendling, and T. A. Pugsley (1983) A rapid filtration assay for soluble receptors using polyethyleneimine-treated filters. Anal. Biochem. 132: 74-81.

Cohen, R. S., F. Blomberg, K. Berzins, and P. Siekevitz (1977) The structure of postsynaptic densities isolated from dog cerebral cortex. I. Overall morphology and protein composition. J. Cell Biol. 74: 181-203.

Cotman, C. W., and D. Taylor (1972) Isolation and structural studies on synaptic complexes from rat brain. J. Cell Biol. 55: 696-711.

Gavish, M. R. S. L. Chang, and S. H. Snyder (1979) Solubilization of histamine $H_{1}, G A B A$ and benzodiazepine receptors. Life Sci. 25: 783-790.

Laemmli, U. K. (1970) Cleavage of structural proteins during the assembly of the head of bacteriophage T4. Nature 227: 680-682.

Laskey, R. A., and A. D. Mills (1975) Quantitative film detection of ${ }^{3} \mathrm{H}$ and ${ }^{14} \mathrm{C}$ in polyacrylamide gels by fluorography. Eur. J. Biochem. $56: 335-341$.

Lippa, A. S., D. Jackson, L. P. Wennogle, B. Beer, and L. R. Meyerson (1982a) Non-benzodiazepine agonists for benzodiazepine receptors. In Pharmacology of Benzodiazepines, E. Usdin, P. Skolnick, J. F. Tallman, D. Greenblatt, and S. M. Paul, eds., pp. 431-440, Macmillan Press, London.

Lippa, A. S.; L. R. Meyerson, and B. Beer (1982b) Molecular substrates of anxiety: Clues from the heterogeneity of benzodiazepine receptors. Life Sci. 31: 1409-1417.

Lo, M. M. S., and S. H. Snyder (1983) Two distinct solubilized benzodiazepine receptors: Differential modulation by ions. J. Neurosci. 3: 2270-2279.

Lo, M. M. S., S. Strittmatter, and S. H. Snyder (1982a) Physical separation and characterization of two types of benzodiazepine receptors. Proc. Natt. Acad. Sci. U. S. A. 79: 680-684.
Lo, M. M. S., R. R. Trifiletti, and S. H. Snyder (1982b) Physical separation and characterization of two central benzodiazepine receptors. In Pharmacology of Benzodiazepines, E. Usdin, P. Skolnick, J. F. Tallman, D. Greenblatt, and S. M. Paul, eds., pp. 165-174, Macmillan Press, London.

Lo, M. M. S., D. L. Niehoff, M. J. Kuhar, and S. H. Snyder (1983) Differential localization of Type I and Type II benzodiazepine binding sites in substantia nigra. Nature 306: 57-60.

Lowry, O. H., N. J. Rosebrough, A. L. Farr, and R. J. Randall (1951) Protein measurement with the Folin phenol reagent. J. Biol. Chem. 193: 265-275.

Matus, A. I., and D. H. Taff-Jones (1978) Morphology and molecular composition of isolated postsynaptic junctional structures. Proc. R. Soc. Lond. (Biol.) 203: 135-151.

Matus, A., G. Pehling, and D. Wilkinson (1981) $\gamma$-Aminobutyric acid receptors in brain postsynaptic densities. J. Neurobiol. 12: 67-73.

Nielsen, M., and C. Braestrup (1980) Ethyl $\beta$-carboline-3-carboxylate shows differential benzodiazepine receptor interaction. Nature 286: 606-607.

Ratner, N., and H. Mahler (1983) Isolation of postsynaptic densities retaining their membrane attachment. Neuroscience 9: 631-644.

Squires, R. F., D. I. Benson, C. Braestrup, J. Coupet, C. A. Klepner, V. Myers, and B. Beer (1979) Some properties of brain specific benzodiazepine receptors: New evidence for multiple receptors. Pharmacol. Biochem. Behav. 10: 825-830.

Trifiletti, R. R., and S. H. Snyder (1983) Partial proteolytic mapping of the benzodiazepine binding subunit of central benzodiazepine receptors in mammalian brain. Soc. Neurosci. Abstr. 9: 404.

Trifiletti, R. R., M. M. S. Lo, and S. H. Snyder (1984) Kinetic differences between Type I and Type II benzodiazepine receptors. Mol. Pharmacol. 26: 228-240.

Wray, W., T. Boulikas, V. P. Wray, and R. Hancock (1981) Silver staining of proteins in polyacrylamide gels. Anal. Biochem. 118: 197-203. 